\title{
TO SAY OR NOT TO SAY? CONSTRUING CONTEXTUAL TABOO WORDS USED BY ACEHNESE SPEAKERS IN INDONESIA
}

\author{
ZULFADLI ABDUL AZIZ \\ Associate Professor \\ English Education Department \\ Syiah Kuala University \\ JalanTeuku Nyak Arief, Darussalam, Banda Aceh 23111, Indonesia \\ e-mail: zulfadli.aziz@unsyiah.ac.id \\ YUNISRINA QISMULLAH YUSUF \\ Assistant Professor \\ English Education Department \\ Syiah Kuala University \\ JalanTeuku Nyak Arief, Darussalam, Banda Aceh 23111, Indonesia \\ e-mail: yunisrina.q.yusuf@unsyiah.ac.id \\ BURHANSYAH BURHANSYAH \\ Senior Lecturer \\ English Education Department \\ Syiah Kuala University \\ JalanTeuku Nyak Arief, Darussalam, Banda Aceh 23111, Indonesia \\ e-mail: burhansyah@unsyiah.ac.id \\ MEUTIA MUZAMMIL \\ Graduate Student \\ English Education Department \\ Syiah Kuala University \\ JalanTeuku Nyak Arief, Darussalam, Banda Aceh 23111, Indonesia \\ e-mail: tyaamuzammil@gmail.com
}

\section{ABSTRACT}

This study describes the types of taboo words used by the Acehnese people in Aceh, Indonesia. Ten language informants in the district were interviewed for this qualitative study. The interviews were recorded and then transcribed prior to analysis. The data were then analysed by the procedures of condensation, display, and conclusion drawing. The findings of the research reveal that the most common taboo types used by Acehnese speakers are taboos of vulgarity or obscenity, epithet, and the taboo of disease. This implies that calling people bad names, talk- 
ing about sex, mentioning incurable or 'repulsive' diseases are among the most taboo discussions in Acehnese society. Taboo words related to religion are found the least in the data, which could imply that these words are small in number because the Acehnese people embrace their religion strongly and thus minimise verbal abuse related to it.

KEYWORDS: taboo • language $\bullet$ culture $\bullet$ Acehnese $\bullet$ Indonesia

\section{N T RODUCTION}

In daily life, people sometimes use a certain language style that has a strong effect when they express their emotions. Words that are considered inappropriate in certain contexts depending on the belief and culture of the speakers are typically called taboo words. Taboo words can have a linguistic effect on speakers (Burridge 2015), and are intrinsically offensive and disturbing to be discussed in public. Therefore, these words are deemed disgusting or revolting when used openly in conversation. In Indonesia, for example, taboo words such as anjing 'dog', babi 'pig', haram jadah 'bastard', among others, are sometimes used to label another person. These names are definitely identified as vulgar, impolite, and disrespectful. Many of these words are also usually used when swearing because they have a strong effect on the listeners in order to express dissatisfaction, resentment, or misery, for example.

Taboo language or words are conditioned by the cultural and religious norms of society (Ahmad et al. 2013). To the Belgians and Japanese, to talk about one's salary is offensive in conversation (Roolant 2014). In the USA, asking a woman about her age is regarded as impolite. In contrast, in China, talking about age and salary is tolerated (Gao 2013). So we can say that taboo words vary amongst societies. Lu Yin (2009: 154) says that "owing to different beliefs and values, and different cultural backgrounds, these cultural differences of politeness are of great importance in cross-cultural communication". Some words and phrases are socially taboo in Acehnese society in light of the fact that conventional traditions or convictions regard them as unethical or wrong. To the Acehnese, taboo words are to be avoided in public to avoid clashes between speakers. Breaking taboos can lead to social punishment. This punishment depends on the type of taboo that is broken. Most of the Acehnese are Muslim (Yusuf and Yusuf 2014), and Aceh Province is the only province in Indonesia which implements sharia law (Zulfadli 2014). If the taboo is against Allah (i.e. God) or Islam, such as cursing God or being apostate from Islam, then the punishment is said to be "self-regulated" (Mouallem 2015: 49), meaning that Allah will punish the speaker of the taboo words in this world or hereafter. In other words, capital punishment for blasphemy is not applied, as is the case in the rest of Indonesia. Due to the strong belief in Allah and punishment on the day of resurrection, Acehnese speakers always pay attention to the context of the conversation when they say taboo words because at times they are strongly recommended not to say those words when communicating.

A number of studies on taboo words among Indonesia's multicultural and multilingual ethnic groups have been made, such as on Karonese (Barus et al. 2018), Batak Mandailing (Hasibuan et al. 2017), Kerinci (Trimadona 2016), Dayak Bekaeh (Sunandar et al. 2018), and Javanese (Nuryantiningsih and Pandanwangi 2018), amongst others. 
Despite this, little research has been performed on taboo in Acehnese. For that reason, this study intends to fill in the gap, focusing specifically on the ethnic Acehnese residing in Aceh Province. We expect the results of this study to add knowledge on Acehnese taboo terms. Understanding this part of culture can help us reflect on and understand the belief and culture of a society, as what is acceptable to one culture may be offensive and insulting to another.

\section{TABOO LANGUAGE}

Taboo is any confinement that brings uneasiness or shame to the interlocutors because of violation of an established tradition (Burduli 2014). This social restriction can cause distress, peril, and harm to the speakers or the community at large. In a society, taboo words are prohibited in everyday discussion when people interact with each other. Ronald Wardhaugh (2006 [1986]) views taboo as the disallowance in any societal purpose which is destructive to individuals and which can lead to uneasiness, embarrassment, or disgrace. Consequently, taboo words bring shame and disrespect that degrade someone's social standing.

The extent to which taboo relies on social homogeneity can change. In everyday life, sometimes speakers deliberately use taboo words depending on certain social goals, such to demonstrate anger, express frustration, or to indicate annoyance (Pluszczyk 2015). Moreover, Timothy Jay (2009: 153) says that the use of "taboo words can communicate emotion information (anger, frustration) more readily than non-taboo words, allowing speakers to achieve a variety of personal and social goals with". In English, for example, to say 'breast' or 'leg' was prohibited in the 19th century because they were taboo words associated with anatomy and sex, therefore to explain parts of a chicken, these parts were even substituted as 'white meat' and 'dark meat' (Yanchang and Runqing 1989: 93). Some cultures avoid mentioning the names of persons who are related by marriage, such as the linguistic taboo in the Oromo ethnic group in Ethiopia. Here, instead of using their respective proper names and those of their in-laws, the husband or wife and in-laws have recourse to euphemistic forms, most of which are coined word forms. For example, a husband or wife must address his or her parents-in-law as abbayyo (father-in-law) and dayyo/daye (mother-in-law) (Mbaya 2002: 232). It is taboo to call them by their names.

Taboo language is used by a society to indicate prohibitions, or words those that require euphemism or mitigation (typically sex, death, and religious transgression), to convey those words (Liamas et al. 2007). At the same time, these words are believed to be harmful to the speakers because they lead to anxiety, embarrassment, or shame for the interlocutors (Wardhaugh 2006 [1986]). Society, as a rule, would remind speakers to avoid using such words. Wardhaugh (2006 [1986]: 239) further affirms that "the penalty for breaking a linguistic taboo can be severe, for blasphemy and obscenity are still crimes in many jurisdictions". This is because particular characteristics in taboo words may lead speakers to misunderstanding, arguments, conflict and confrontation. In the present day, younger generations even use taboo words as a joke. Ningjue Zhou (2010) reveals that on the Internet, jokes about sex are now becoming common in daily chats. In certain contexts, taboo words are also used as humour. However, this of course also depends on the speakers, their relationships and the milieu of their conversation. 
Taboos have been classified into several types. Stephen Ullmann (1977) has proposed that forbidden or taboo words are categorised into three types: the taboo of fear, the taboo of delicacy, and the taboo of respectability. Meanwhile, Edwin Battistella (2005) classifies taboos into designation, irreverence, obscenity, foulness, and vulgarity. Furthermore, Jay (1999) presents taboo language as divided into swearing, vulgarity, profanity, verbal mishandling, offence, verbal animosity, rude words, racial slurs, vulgarity, and slang. In terms of swearing, Tony McEnery (2006) expressly links it with offence, yet additionally places a setting inside which an offence would happen. Appalling language, in this sense, is any word or expression which, when utilised in what one can call considered discussion, is probably going to cause offence. The next subsections discuss some types of taboo as proposed by the literature: the taboo of fear, delicacy, respectability, profanity, epithet, swear, obscenity (sex), and vulgarity.

The taboo of fear is the prohibition of words concerning something that is mentioned. The context can lead to peril, bad luck, and even death (Ullman 1977). The taboo of fear is generally driven by culture. For example, in the Shona culture, in Africa, people should not strip tree bark from a tree where someone else has already stripped it. If someone breaks this rule, bad luck will come to his or her mother. (Chigidi 2009) Accordingly, William Lungisani Chigidi (2009) explains that when the word maivako 'your mother' is being uttered to a child to explain this prohibition, a Shona child would react with extreme fear or insecurity. Similarly, in one of the ethnic groups in Indonesia, the Melayu Belantik in Riau, it is taboo to eat sugarcane at night, because by doing so it is believed that the person's mother will die. So, to hear the phrase nanti mati emak 'your mother will die' creates fear in any child (see Syahrir 2016).

The taboo of delicacy is concerned with prohibition of words relating to a certain disease (Ullman 1977). In this context, an example is leprosy. In Indonesia, leprosy is considered a disease that passes from generation to generation because the family is cursed by God (Tarigan 2013). If a person comes into contact with a sufferer, he or she will be cursed and contract the disease. In some areas of the country, people who suffer from this disease are exiled to an isolated area where they have no contact with society. Rehabilitation centres for people with leprosy are usually located in isolated places, such as Donorojo near the beaches of Jepara, Central Java (Febriyantoro et al. 2017), and in Podi Amat village, Alue Naga, Aceh. ${ }^{1}$ And thus, bearing in mind that lepers are thought to be cursed by God, to call out loud someone kusta, 'leprosy', in Indonesia is taboo.

The taboo of respectability is basically related to gender (Ullman 1977). For example, in most European countries during the 1950s, it was prohibited for women to smoke. There were endless debates on this prohibition, and there was a long struggle for women to get permission to smoke (Amos and Haglund 2000). Women who were caught smoking were labelled 'bitch' because they were deemed to go against the societal taboo and be rebellious. Smoking was seen as a danger to their morals and values. In Bahasa Indonesia, taboo words relating to respectability also concern women as well. For example, the word pelakor 'a woman who has an affair with another woman's husband' and ayam kampus 'college hen' for a prostitute who studies at university are addressed to women (Stevenson 2013). 
The taboo of profanity relates strongly to religion (Jay 1999). In this case, the speaker tends to relate to God (and other aspects of religion) with expressions of anger or disappointment (Mercury 1995). An example of this in English is the name of God, Allah. Horn McLamb (2016) provided an example of some Americans being afraid of hearing the word Allah on a plane after the hijack and attack on the US on September 11, 2001. These words are considered taboo as they are presumed to be related to plane hijacking and such attacks. Due to journalism practice today, false news about Islamist terrorism affects Western citizens' reactions and influence non-Muslims' out-group views of Muslims (von Sikorski et al. 2017).

In Indonesia, when a person is selfish or cunning, and is willing to sacrifice others for his or her benefits, he or she is called Yahudi 'Jewish'. The long-term Israeli attack on the Palestinian land has contributed to Muslim intolerance of Jews (Caro 2015), and thus, to call someone a Jew in Indonesia is insulting. Another example is the word kafir, 'infidel', addressed to a non-Muslim. This word is used when a person becomes furious with his or her interlocutor, who encourages verbal attacks of a religious nature (Stevenson 2013).

The taboo of epithet includes expressions of insult associated with race, ethnicity, sex, sexuality, appearance or handicap (Batistella 2005). John Anthony Cuddon (1979) describes how epithet is an expression in which a label is exchanged with another word. Examples of epithet are 'faggot' (homosexual male) for males, 'nigga' (coloured person) for African people, and so on (Croom 2015). This can happen to show that the person who expresses the word is spurred by disappointment or outrage. In spite of the fact that there are different definitions for these exchanged terms, they share a greater number of similarities than differences.

Swearing or cursing is using the bad language to express anger or disappointment and direct it to a certain person who is the object of anger (Jay 1999). These expressions are considered verbal attacks to the target individual or group, expecting that the target feels the harshness of the language of the emotion contained therein (for instance, the expression 'eat shit and die!') (Mercury 1995). Swearing might be proper in some circumstances and not viewed as only ill-mannered or discourteous in order to communicate the speaker's passionate state. As opposed to most other discourse, swearing is basically intended to pass on obvious importance; the implication of the words themselves are essentially interpreted as suggestive (Jay and Danks 1977).

Field investigations into swearing (Jay and Janschewitz 2008) have shown that most instances of swearing in of public are conversational. In Indonesian, an example is the word mampus, 'dead'. This word is mentioned when someone is angry with a person; the word is used to attack the target verbally and to cause him or her pain. The other example is mati kau 'you (should) die', which is also similar to the prior example both in meaning and usage (Stevenson 2013).

The taboo of (sexual) obscenity is defined as "indecent words and phrases" (Montagu 2001: 105) because they refer to expressions that characterize sex-differentiating anatomy or sexual acts in an offensive way (Battistella 2005). Taboo words that are common in this type are 'fuck' and checazzo (Italian 'what the cock') (Harbeck 2015). Particularly in Indonesian, the word susu, 'milk', is also considered vulgar on certain occasions because it alludes to women's breasts (Stevenson 2013). On the other hand, the word burung, 'bird', is usually addressed to the man's intimate organ. In most settings, these 
expressions can be viewed as inhumane, disagreeable, and hostile (Mercury 1995). Thus, almost all of society forbids obscene language, confining use of these articulations in one or other way (Battistella 2005). In some cases, when words like these are required speakers will use code words to depict sexual body parts when conversing.

Vulgar language is utilised to degrade a certain thing or individual. For example, 'he needs to take a crap!' means that he needs to go to the toilet. To curse or swear by saying 'shit', despite being commonly heard in daily conversation, is also vulgar when said in public.

\section{METHOD}

As mentioned above, the purposes of this study is to identify types of taboo language used by the Acehnese in Bireuen district, Aceh, Indonesia. Qualitative methods are used in order to describe the types of and factors relating to taboo language. The object of this study is taboo words in Acehnese. Five Acehnese males and five females aged 50 years or older were selected as language informants from various occupations (farmers, teachers, businessman and businesswoman, civil servants). The entire process of data collection was conducted in 2019.

Semi-structured interview was used as a way of obtaining data. The informants were asked ten questions that were adapted from Ullmann 1977, Battistella 2005, and Jay 1999. In this study, interviews were conducted face to face with participants using the Acehnese language. They were asked to mention any taboo words that came to mind or any taboo words that they were familiar with. To understand how these words were used within the social context, interviewees asked for further explanations and examples of use. To avoid losing important information during the interview, an audio recorder was used. After the data were collected, they were then analysed using a qualitative technique as suggested by Miles et al. 2014. This consists of three procedures: data condensation, data display, and conclusion drawing. Data condensation is useful to find out the types and factors relating to words used by Acehnese people in Bireuen district. This step was applied in order to focus on the specific type of taboo language used in this district as Aceh consists of various districts with different accents, dialects and local languages. Data were used to present the social contexts in which these taboo words were employed in addition to its main purpose of informing the essential process of conclusion making.

\section{RESULTS AND DISCUSSION}

Based on the research questions formulated above, this research intended to classify the types of taboo that are most commonly employed by Acehnese society in Bireuen district. Basically, the data showed that every type of taboo mentioned in Ullmann 1977, Battistella 2005, and Jay 1999, is used in the target group (i.e. taboos of profanity, epithet, vulgarity, swear, obscenity, fear, disease, respectability, sex, and certain body parts). The data show that of the ten taboos, the taboos of epithet, vulgarity, and disease are most commonly employed in Acehnese discourse. 
Epithet is here given to mean expressions that call other people bad names, usually to show anger or negative emotions. Use of these words are often linked to ethnicity, animals, race or sexuality (Batistella 2005). Most Acehnese used epithets relating to animals.

D1 lagè asè 'like a dog' or lagè bui 'like a pig' - expression of anger towards someone who does something depraved

D2 lagè buru juek balè 'like a widowed bird' - expression towards someone with a blabbermouth

D3 bank 47 siujông 'at the edge of bank 47' or bank 48 siujông 'at the edge of bank $48^{\prime}$ - a person who lends money with a very high interest

D4 abah lagè manok tôh boh 'the mouth is like a chicken laying eggs' - a person who talks too much, especially about other people's misfortune

D5 lagè pukoe manok burék 'like the private part of a striped hen' - a person who talks too much, especially about other people's misfortune

D6 lalat mirah 'a red fly' - a person who likes to slander or spread false news

D7 hanai-teupureudôk'does not know anything' - a person who does not know anything and acts carelessly.

Examples D1, D2, D4, D5 and D6 include taboo phrases represented in the form of animals. Edmund Leach (2000) used the expression 'animal abuse' to refer to tendency to call a person by the name of an animal (such as bitch, pig, cow).

In the Acehnese, dogs and pigs are the most common animals linked to the taboo of epithet. Most Acehnese are Muslims, a religion that forbids the eating of pigs because they are impure and judged as one of the dirtiest animals as they feed on dirt. In addition, a dog's saliva is considered impure, so if it licks someone or something that is being held by someone, the person and thing must be washed seven times, the first time with earth or dirt. Therefore, it is forbidden in this religion to keep dogs as pets that live indoors. Dogs can be owned for the purpose of hunting, guarding livestock, and guarding crops, but it should live outside the house. Since both of these animals are considered impure, many taboo phrases in Acehnese are related to dogs and pigs. Interestingly, there is a similarity to English in this case as both languages include words that express anger through comparison with dogs or pigs.

Chickens and ducks are common birds that the Acehnese, especially in the villages, breed in their backyards. These animals are considered noisy especially during the mating season. As for the red fly, it is well known to spread diseases. And thus, people who gossip, perpetrate hoaxes and use slander are associated with birds and insects.

Taboos in relation to banks are associated with riba, a concept in Islam that refers to growth, increasing or exceeding, and is forbidden. Riba is seen to conflict with brotherhood and sympathy and is based on greed, selfishness, and hard-heartedness. It is also one of the seven major Islamic sins, which will lead a believer to Hell. To associate someone with these phrases is considered taboo by the Acehnese society. 
The next type of taboo is vulgarity, also connected to the taboo of obscenity and the taboo of sex in Acehnese society. Robin-Eliece Mercury (1995) stated that this type of taboo covers words or phrases that are inhumane or hostile. Examples are presented below:
D8 jak 'ok ma 'do sexual intercourse with your mother'
D9 aneuk bajeung 'bastard'
D10 lam breut ma keuh 'in your mother's private part'
D11 aneuk tét ma keuh 'your mother's inner private part'
D12 pap ma keuh 'do intercourse with your mother'
D13 lét ma 'chase your mum'
D14 kureung aja 'uneducated'
D15 bijèh hana get ka turôt ku keuh 'ill-bred like your father'
D16 kajak lét asè keudéh 'go chase the dog'
D17 paléh lagè ku keuh 'evil like your father'
D18 lam pukaima 'in your mother's private part'

The expressions are mainly associated with a woman's private parts. To talk about sex and private parts in Acehnese culture, whether in public or private, is considered taboo. This does not only apply to the Acehnese, but to most societies around the world, where sex is surrounded by a legion of social norms, religious restrictions, and moral taboos (Heflick 2011). There is an attempt by society to control people's sexual behaviour, especially regarding women. Apparently, this notion enforces the stigma that sexual relationships outside of marriage that produce offspring is associated with great dishonour since women are the ones who can get pregnant. They are the ones who 'bear a mark' from this encounter. Somehow, society comes to a decision that they have more control to prevent the act.

However, Islam has emphasised the compatibility of gender equality, with women holding a high position as mothers. In the Holy Qur'an, as translated into English by Abdullah Yusuf Ali (1946), in Surah Al-Isra (17:23-24), Islam commands kindness, respect, and obedience to parents, and specifically emphasises and gives preference to the mother (Surah Luqman 31:14). The Prophet Muhammad also prioritised mothers three times more than fathers (the hadith narrated by Bukhari number 5971, and the hadith narrated by a Muslim number 2548). Seen from this perspective, it can be said that Islam regards women as having a higher position when they are mothers, as well as their having their own rights as individuals. For that reason, to insult someone's mother in Acehnese is judged taboo and can cause rage.

Moreover, this study also identified taboo of certain body parts in Acehnese society and how they should not be mentioned directly. Most societies do not allow mention of the same sexual autonomy or body parts for men as they do for women (Owens 2002), and this leads to a majority of the taboo words being specifically female (Stevenson 2013). Thus even today women's body or body parts are viewed as physical objects of male sexual desire (Szymanski et al. 2011), something that is equally true in Acehnese society. In Islam, a woman is required to wear the hijab (which covers the entire body from head to toe, except face and hands) when she is present among men outside her 
immediate family. The data also show that in Acehnese society most of the taboos of this type are related to a woman's body parts.

D19 boh krèh 'a male's private part'

D20 capôk 'a female's private part'

D21 pe-ong 'a female's private part'

D22 capah 'a female's private part'

D23 pukoe 'a female's private part'

D24 bret 'a female's private part'

D25 apam 'a female's private part'

D26 bohpik 'a female's private part'

The data from D19 to D26 are all words of sexual anatomy. From eight taboo words, seven are related to women. In this case, these are 'sexual' body parts, and thus they are similar to vulgarity and obscenity.

\section{TABOO OF DISEASE}

The taboo of disease is also among the taboos most commonly employed by the Acehnese in arguments. Diseases here include both physical and mental diseases. It is common for societies to fear certain diseases and in order not contract them, avoid them as much as possible, even to the point of not saying the names of the diseases (Ross and Halim 1989). Taboos relating to disease in Acehnese culture are:

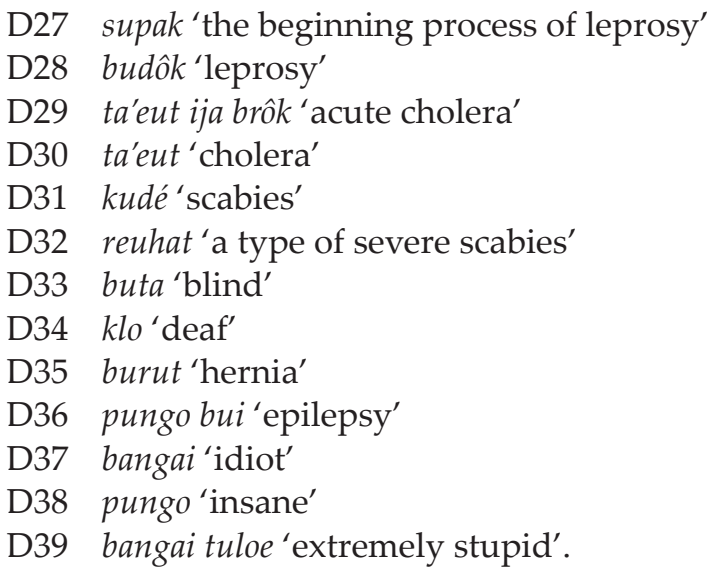

There were times when skin diseases were incurable and therefore they are still taboo (see examples D27-D32). Moreover, mental illness and stupidity are also taboo in public. There are Acehnese who still believe that sufferers of these sorts of illness are victims of witchcraft or are possessed by evil spirits (see Yusuf 2002; Yusuf and Yusuf 2014). To curse people with the names of these diseases is hurtful for people who are sufferers or have a family member who suffers from them. Some Acehnese even believe that these diseases are evil and are the results of curses and that one can be infected just by saying the names. 
The taboo of profanity is founded on religious belief (Mercury 1995). These words are forbidden because they are impolite or harsh from a religious point of view, specifically, because most Acehnese are Muslim, from the Islamic point of view.

D40 lagè kaphé 'like a non-Muslim' - a person who is reluctant to follow Islamic principles

D41 lagè yahudi 'like a Jew' - a person who perpetrates evil deeds.

These two expressions are prohibited because to the Acehnese they imply a nonbeliever - someone who does not believe in the one God, Allah, and his messenger, the Prophet Muhammad. Muslims believe that non-believers will not enter Heaven in the hereafter. In addition, the Jewish people are known by Acehnese Muslims to be those who despise Muslims. For the newer generation, this belief might be associated and traced to the prolonged war between the Palestinians and the Jews in Palestine. However, for the older generation it might be cause of Christiaan Snouck Hurgronje's interference in politics and religion in order to pacify the Acehnese resistance and get them to accept the Dutch rule and government, which started around 1873 (see more in Siegel 2014). James Siegel (2014) remarks that at the time, Hurgronje and General Joannes Benedictus van Heutsz's aggression toward the Acehnese people, and their plan to conquer Aceh, played a part in the development of hate. In Hurgronje's observation, instead of the use of formal personal pronouns, the Acehnese would simply use the familiar term kafir ('infidel'). Although this was used without any specific resentment or hostile sentiment toward the Dutch, it was surely an expression of the local belief, showing how the unbelievers merited nothing more than contempt, and certainly not respect. There is, of course, no intention to degrading or blaspheme other beliefs. The expressions above are merely a way of expressing frustration towards others who originated within the colonial past and were associated with historical colonial sentiments. Additionally, the intermixing of Hindu and Buddhist religious practice, custom, and cultural elements before Islamic values were introduced in Aceh influenced the use of taboo words associated with spiritual beings.

\section{TABOO OF SWEARING}

The taboo of swearing relates to an attack on a person verbally rather than physically (Mercury 2005). The expressions in this taboo found in Acehnese society are as depicted in D42-D48.

D42 beukeumah ma keuh 'your mum should die'

D43 beui-pajôh até keuh lé rimueng 'the tiger should eat your liver'

D44 beuphang phoe keuh 'you should perish and become debris'

D45 i-takkeuh lé geulanteu barô ka thè droe 'you should get struck by a bolt of lightning so that you know how bad you are'

D46 beujeut keu darah gapah 'may it be your flesh and blood'

D47 bah ji-timoh bara singkè 'a fiery torch should grow on you'

D48 beumaté keuh 'you should be dead'. 
With swearing the speaker intends to curse and bring bad luck to the interlocutor. As elaborated earlier, children hold mothers in high regard compared to fathers in Acehnese society. Therefore, swearing using their mothers' names is completely unacceptable (such as in D42). Tigers are among jungle animals that are greatly feared by the Acehnese. Tigers are now becoming scarce on Sumatra Island, but it was once an animal that often attacked villages in the hunt for food, or attacked hunters while they were hunting for food in the jungle. Therefore, to curse someone using the tiger's name as in D43 is horrifying.

Aceh features a tropical rainforest climate and heavy rain with lightning and thunder are common during the rainy season. There are many cases of people being struck by lightning, and thus to swear at someone using this expression, as is shown in D45, is offensive. Moreover, the Acehnese believe in the existence of devils as part of their religion. Devils, determined by God to enter Hell, can possess human beings and cause them to do evil things. To curse someone to grow a fiery torch on their body is akin to calling him or her a devil.

\section{TABOO OF FEAR}

To the Acehnese the taboo of fear is related to fear of devils or other creatures from superstition. According to Ullmann (1977), this type of taboo is believed to imperil life when violated. Examples found in Acehnese society are illustrated below.

D49 Balum blidi 'ghosts that occupy rivers'

D50 Beuno 'ghosts that pressure people and can kill them in their sleep'

D51 Geunteut 'ghosts that only appear during the evening and kidnap people to eerie places'

D52 Rimueng 'tiger'

D53 Cagè 'bear'

D54 Gajah 'elephant'.

Balum blidi, beuno, and geunteut are among the creatures that the Acehnese believe exist. Yunisrina Qismullah Yusuf and Qismullah Yusuf (2014) have discussed the existence of these creatures or ghosts and how they take part in the Acehnese cultural prohibitions. Muslims do not believe that dead people can return as ghosts, so if someone feels that he or she has encountered a ghost, this is deemed to be the work of the devil. In Aceh both animism and dynamism can be traced back to Hindu and Buddhist teachings long before Islamic values were introduced to the Acehnese people (Hasan et al. 2018). They propose that the Aceh community was influenced by the mythical relics of both religious practices; even now, those who live in rural territory tend to be passionate about their superstitious beliefs, to the extent of being fanatical. These traditional beliefs are integrated within both personal and community dimensions. They were part of all religious and non-religious ceremonies within day-to-day life, with people believing that good deeds manifested from these convictions. Therefore, society strongly encouraged people to obey all kinds of prohibition and avoid meeting ghosts, as these were bad omens. However, Hasan et al. 2018 concludes that the Acehnese people perceived ghosts somehow differently than how the common people thought of paranormal 
beings. Rather than a malicious supernatural creature that manifested from the soul of a dead person, ghosts were thought of as genies of some kind. The natives called them burong or geunteunt.

Bear, tiger, and elephant are powerful animals that are believed to rule the jungle. Thus, mentioning their names in certain situations or at certain times, such as swimming in rivers, hunting in the jungle, or walking at twilight, is taboo. It is believed that these animals will approach the person who mentions their names.

\section{CONCLUSION}

The motivations behind each of the taboo language classifications depend on the contextual situation. It is important to point out that rather than affecting a large number of people or even the whole of society, the utterance of taboo words generally only occurs and/or affects those who are directly involved in a particular situation. This situation includes both parties and usually orbits an issue known to both, thus making it personal. When this privately delicate issue ignites a heated argument, taboo words might make an appearance.

While taboo words are usually met with disapproval, some can be used humorously or persuasively. People usually use epithets to express anger towards a person whom they found to be doing or saying something that morally contradicts societal values or norms. Because it usually touches on topics such as ethnicity, race, and sexuality, this kind of taboo word has the capacity to degrade someone's personal value in some ways to the extent of dehumanising them by comparing them to animals or another kind of insufficient object. On the other hand, it has been observed as being used for humour among closed groups of friends or when speaking by those who are familiar and equal to each other. Both parties know and are aware that there is no bad feeling, bad intention, or malice involved. However, people may be quick to deplore this kind of language simply because of the bad associations that the words have.

The same thing can be said about the taboos of vulgarity and swearing. However, unlike the case of epithet, people generally tend to avoid using these types of word simply because of the sensitivity they represent. Vulgarity and swearing mainly centre around two subjects, the mother and the intimate parts of the human being. Seeing how much respect people have for mothers in general and how sacred the mother is to the Acehnese, people are reluctant to use these words. Furthermore, while most taboo words directly affect those who are involved in the conversation, some of the vulgarity taboo revolves around a third party, the mother. Thus, these insult have a greater impact than the taboo of epithet.

While, in most cases, epithets, vulgarity, and swearing occur out of a frustration that leads to anger, the taboo of profanity is because the speaker feels a higher degree of outrage toward the subject. There is a small chance that this type of taboo language comes with an encounter in daily life. First, because people are unconsciously aware of the blasphemy this represents regardless of the religion involved. Second, there is a subconscious awareness that prevents people avoiding talking and associating inappropriate things/conditions with religion, let alone questioning one's faith in their own (i.e. Islam). For this reason, this taboo language is rarely said or encountered daily. 
Meanwhile, there is no significant meaning or intention in the taboo of fear. Today, these words are usually only used to frighten children or express humour when speaking with those of the same status in society. However, in the past people have used these words to actually express fear of something. Mainly because of the supernatural and mythical factor, these words are symbolic. These two contradictory situations within two periods of time might be connected with the fact that the current generation pays little to no attention at all to ghosts. In regard to the taboo of disease, these words should be avoided because they imply that someone might indirectly degrade or devalue others by using them, and thus humiliate them.

Based on these findings it can be concluded that most types of taboo used by the Acehnese are taboos of epithet, vulgarity, and disease. This implies that calling people bad names, talking about sex, mentioning incurable or 'repulsive' physical and mental diseases and illness are among the most taboo discussions in Acehnese society. As a result, using these taboo words in communication in order to provoke interlocutors' anger and frustration works more promptly than non-taboo words, permitting speakers to achieve a variety of personal and social goals in interaction. Meanwhile, taboo words relating to religion are found the least in the data. This may imply that the Acehnese people are strongly Muslim and so minimise verbal abuse related to their own religion.

In conclusion, there are two main differences in what constitutes taboo language within Acehnese society: one is primarily used to curse or swear, and the other is generally considered inappropriate in certain contexts. The difference in contextual use between these types depends on whether the words are being used to attack someone or as humour or persuasion. The former is on par with many curse words being used in many societies around the world, while the latter is centres on what are considered sensitive topics. Usually, the appeal of using this language as humour occurs because of the sense of mockery it represents rather than the tense atmosphere it can create.

Despite answering the research question of this study, some limitations must be recognised and suggestions for future research proffered. Further studies on taboo language used in other parts of Indonesia should be conducted so that comparisons can be drawn. Seeing that Indonesia comprises multicultural, multi-ethnic, and multilingual people, these comparisons could lead to other studies related to historical linguistic and cultural influences. Other aspects of taboo such as the functions of taboos, taboo signs and actions are also recommended for future research. Considering other way of gaining data is also encouraged. The results of these studies could be used for comparison with other taboo language around the world.

NOTES

1 Similarly, in Hawaii, the Kalaupapa peninsula accommodated 8,000 people with leprosy from 1866 to 1969 (Senthilingam 2015). 


\section{REFERENCES}

Ahmad, Kursheed; Mamuna Ghani, Mahtab Alam and Tahir Gul. 2013. A Sociolinguistic Study of the Linguistic Taboos in the Pashtoon Society. - International Researchers 2 (1): 36-41.

Ali, Abdullah Yusuf, transl. 1946. The Holy Quran. Washington, DC: The American International Printing Co.

Amos, Amanda and Margaretha Haglund. 2000. From Social Taboo to "Torch of Freedom": The Marketing of Cigarettes to Women. - Tobacco Control 9 (1): 3-8. DOI: https://doi.org/10.1136/ tc.9.1.3.

Barus, Jumat; Robert Sibarani, Amrin Saragih and Mulyadi. 2018. Local Wisdom of Taboos in Karo Language. - Language Literacy: Journal of Linguistics, Literature and Language Teaching 2 (2): 94-102. DOI: https://doi.org/10.30743/11.v2i2.671.

Battistella, Edwin. 2005. Bad Language: Are Some Words Better than Others? Oxford: Oxford University Press.

Burduli, Natalia. 2014. How Far do Students Acknowledge the Meaning of Taboo Words? - Russian Federation European Researcher 73: 756-759.

Burridge, Kathryn. 2015. Taboo Words. - The Oxford Handbook of the Word, edited by John R. Taylor. Oxford: Oxford University Press, 270-283. DOI: https://doi.org/10.1093/oxfor dhb/9780199641604.013.017.

Caro, Isaac. 2015. Anti-semitism, Anti-zionism and Israeli Palestinian Conflict from 2000 to 2014: Some Visions from Latin American Southern Cone. - Trames 19 (3): 289-307. DOI: https://doi. org/10.3176/tr.2015.2.05.

Chigidi, William Lungisani. 2009. Shona Taboos: The Language of Manufacturing Fears for Sustainable Development. - The Journal of Pan African Studies 3 (1): 174-188.

Croom, Adam M. 2015. The Semantics of Slurs: A Refutation of Coreferentialism. - Ampersand 2: 30-38. DOI: https://doi.org/10.1016/j.amper.2015.01.001.

Cuddon, John Anthony. 1979. A Dictionary of Literary Terms. Chatham: W. \& J. Mackay Limited.

Febriyantoro, Widya Regsha; Alifia Safira Srihastuti and Muhammad Haikal Efendi. 2017. An Ancient Local Wisdom in Indonesia as a Power to Treating People Affected by Leprosy in Social Way. - Proceedings of the Tenth Asia-Pacific Conference on Global Business, Economics, Finance and Social Sciences. Hong Kong: J. A. Alpha Business Research \& Publishers Pvt. Ltd.: $1-8$.

Gao, Chunming. 2013. A Sociolinguistic Study of English Taboo Language. - Theory and Practice in Language Studies 3 (12): 2310-2314. DOI: https://doi.org/10.4304/tpls.3.12.2310-2314.

Harbeck, James. 2015. Mind Your Language! Swearing Around the World. - BBC Online. http:// www.bbc.com/culture/story/20150306-how-to-swear-around-the-world (accessed September 30, 2020).

Hasan, Ridwan Muhammad; Iskandar Ibrahim and Saifuddin Dhuhri. 2018. Aceh Islamic Society (Beliefs in Animism and Dynamism). - Budapest International Research and Critics Institute (BIRCI-Journal) Humanities and Social Sciences 1 (3): 306-312. DOI: https://doi.org/10.33258/ birci.v1i3.54.

Hasibuan, Siti Lanna; M. Nur Mustafa and Elmustian Elmustian. 2017. Fungsi sosial pantang larang masyarakat Batak Mandailing Simangambat Padang Lawas Utara. - Jurnal Online Mahasiswa Fakultas Keguruandan Ilmu Pendidikan Universitas Riau 4 (1): 1-10.

Heflick, Nathan. 2011. Why Is Sex So Taboo? - Psychology Today. https://www.psychologytoday. com/us/blog/the-big-questions/201104/why-is-sex-so-taboo (accessed September 30, 2020).

Jay, Timothy. 1999. Why We Curse. Philadelphia, PA: John Benjamins. DOI: https://doi. org/10.1075/z.91.

Jay, Timothy. 2009. The Utility and Ubiquity of Taboo Words. - Perspectives on Psychological Science 4 (2): 153-161. DOI: https://doi.org/10.1111/j.1745-6924.2009.01115.x. 
Jay, Timothy B. and Joseph Danks. 1977. Ordering of Taboo Adjectives. - Bulletin of the Psychonomic Society 9 (6): 405-408. DOI: https://doi.org/10.3758/BF03337038.

Jay, Timothy and Kristin Janschewitz. 2008. The Pragmatics of Swearing. - Journal of Politeness Research 4 (2): 267-288. DOI: https://doi.org/10.1515/JPLR.2008.013.

Leach, Edmund. 2000. Animal Categories and Verbal Abuse. - Essential Edmund Leach 1: Anthropology and Society. New Haven, CT: Yale University Press, 322-343.

Llamas, Carmen; Louise Mullany and Peter Stockwell, eds. 2007. The Routledge Companion to Sociolinguistics. New York, NY: Routledge Taylor \& Francis Group. DOI: https://doi. org/10.4324/9780203441497.

Mbaya, Maweja. 2002. Linguistic Taboo in African Marriage Context: A Study of the Oromo Laguu. - Nordic Journal of African Studies 11 (2): 224-235.

McEnery, Tony. 2006. Swearing in English: Bad Language, Purity and Power from 1586 to the Present. London: Routledge.

McLamb, Horn. 2016. Is the Fear of Islam Rational? - Journal of Political Sciences and Public Affairs 4 (1): $1-5$.

Mercury, Robin-Eliece. 1995. Swearing: A 'Bad' Part of Language; A Good Part of Language Learning. - TESL Canada 13 (1): 28-36. DOI: https://doi.org/10.18806/tesl.v13i1.659.

Miles, Matthew B.; Michael A. Huberman and Johnny Saldaña. 2014. Qualitative Data Analysis: A Methods Sourcebook. Los Angeles, CA: Sage Publications.

Montagu, Ashley. 2001. The Anatomy of Swearing. Philadelphia, PA: University of Pennsylvania Press.

Mouallem, Summer. 2015. Interpreting Taboo: Developing and Evaluating Strategies in the Transfer of Taboo Language. - The Eurasia Proceedings of Educational and Social Sciences 3: 48-56.

Nuryantiningsih, Farida and Wiekandini Dyah Pandanwangi. 2018. Politeness and Impoliteness in Javanese Speech Levels. - Advances in Social Science, Education and Humanities Research 166: 383-387. DOI: https://doi.org/10.2991/prasasti-18.2018.70.

Owens, Richard. 2002. The Mythological Role of Gender Ideologies: A Cross-Cultural Sample of Traditional Cultures. - Nebraska Anthropologist 76: 57-71.

Pluszczyk, Adam. 2015. An Analysis of Swearing from a Positive Perspective. - Alfinge 27: 103127.

Roolant, Lisa. 2014. How People from Different Countries Feel about Discussing Salary. - Business Insider. https://www.businessinsider.com/discussing-salary-around-the-world-2014-3?IR=T (accessed October 5, 2020).

Ross, W. Felton and Paulus W. Halim. 1989. Penyakit Kusta untuk Petugas Kesehatan. Jakarta: Gramedia Press.

Senthilingam, Meera. 2015. Taken from Their Families: The Dark History of Hawaii's Leprosy Colony. - CNN. https:/edition.cnn.com/2015/09/09/health/leprosy-kalaupapa-hawaii/index. html (accessed October 5, 2020).

Siegel, James T. 2014. Victory without Surrender: The Jihad in Aceh. - Regards croisés sur Aceh. Archipel 87: 29-62. DOI: https://doi.org/10.3406/arch.2014.4455.

von Sikorski, Christian; Desirée Schmuck, Jörg Matthes and Alice Binder. 2017. “Muslims Are Not Terrorists": Islamic State Coverage, Journalistic Differentiation between Terrorism and Islam, Fear Reactions, and Attitudes toward Muslims. - Mass Communication and Society 20 (6): 825-848. DOI: https://doi.org/10.1080/15205436.2017.1342131.

Stevenson, Sacha. 2013. 27 Indonesian Swear Words. - Youtube. https://goo.gl/YhuUaK (accessed October 5, 2020).

Sunandar, Andi; Nanang Heryana and Agus Syahrani. 2018. Leksikon tabu dalam bahasa Dayak Bekaeh. - Jurnal Pendidikan dan Pembelajaran Khatulistiwa 7 (4): 1-12.

Syahrir, Elvina. 2016. Ungkapan pantang larang masyarakat Melayu Belantik. - Madah 7 (2): 237250. DOI: https://doi.org/10.31503/madah.v7i2.433. 
Szymanski, Dawn M.; Lauren B. Moffitt and Erika R. Carr. 2011. Sexual Objectification of Women: Advances to Theory and Research. - The Counseling Psychologist 39 (1): 6-38. DOI: https://doi. org/10.1177/0011000010378402.

Tarigan, Nuah Perdamenta. 2013. Masalah kusta dan diskriminasi serta stigmatisasinya di Indonesia. - Humaniora 4 (1): 432-444. DOI: https://doi.org/10.21512/humaniora.v4i1.3453.

Trimadona, Eliza. 2016. An Analysis of Swear-Words Used in Pondok Tinggi Dialect of Kerinci Language. - Islamika: Jurnal Ilmu-Ilmu Keislaman 16 (1): 67-81.

Ullmann, Stephen. 1977. Semantics: An Introduction to the Science of Meanings. Oxford: BasilBlackwell.

Wardhaugh, Ronald. 2006 [1986]. An Introduction to Sociolinguistics. 5th edn. Oxford: Blackwell Publishing Ltd.

Yanchang, Deng and Liu Runqing. 1989. Language and Culture: A Comparison of English and Chinese Culture. Beijing: Foreign Language Teaching and Research Press.

Yin, Lu. 2009. Cultural Differences of Politeness in English and Chinese. - Asian Social Science 5 (6): 154-156. DOI: https://doi.org/10.5539/ass.v5n6p154.

Yusuf, Yunisrina Qismullah. 2002. Ethnography of Acehnese Society: Cultural Prohibitions with Reference to Education. Bachelor's thesis. Syiah Kuala University.

Yusuf, Yunisrina Qismullah and Qismullah Yusuf. 2014. Contemporary Acehnese Cultural Prohibitions and the Practice of Mystical Threats. - Kemanusiaan: The Asian Journal of Humanities 21 (2): 21-53.

Zhou, Ningjue. 2010. Taboo Language on the Internet: An Analysis of Gender Differences in Using Taboo Language. Master's thesis. Kristianstad: Kristianstad University.

Zulfadli. 2014. A Sociolinguistic Investigation of Acehnese with a Focus on West Acehnese: A Stigmatised Dialect. Doctoral dissertation. Adelaide: University of Adelaide. 